\title{
Analysis on Financial Pressure of Coal Enterprises in Information Age
}

\author{
Yaping $\mathrm{Ji}^{1}{ }^{*}$, Huanhuan $\mathrm{Zhu}^{2}$ \\ ${ }^{1,2}$ School of Lanzhou University of Technology, Lanzhou, Gansu, 730050 , China .
}

\begin{abstract}
Driven by technological innovation, the domestic economy is developing rapidly . However, the phenomena of excess capacity, weak market demand and vicious competition in coal industry put forward a severe test for coal enterprises to deal with the financial pressure caused by the dual factors of market and system in the information age. Under the influence of market and system factors, coal enterprises should be based on the background of the current era , realize their financial pressure correctly, and seek a sustainable development path .
\end{abstract}

\section{Introduction}

In the information age, the main factors that cause the financial pressure of coal enterprises are market factors and system factors. The influence of market factors is divided into internal and external market factors. The internal market factors are mainly due to high production cost , unreasonable industrial structure and poor enterprise benefit . The external market environment is mainly due to the reduction of market demand and excess capacity. The system factors mainly include the system of mineral resources, environment and safety. The system of mineral resources has further improved the construction of mineral rights and increased the cost of coal enterprises, although our country coal mine safety production laws and regulations system along with the development of the Socialist market economy system , but also need to continue to supplement and improve . The above factors make the uncertainty of the process balance in the coal market increase, the development of the industry is unbalanced and inadequate, and the problem of cutting off production capacity and the separation of "Three supplies and one industry"from the taxes and fees of the coal enterprises is quite serious, then causes the coal enterprise's financial pressure to increase day by day .

\section{Literature Review}

Research Abroad is mainly focused on factor cost control , Hyojoo Son and Changwan Kim (2010) studied how information management system can be used in enterprise cost control to play the role of environment-related cost control [1] . Stefan Schaltegger and D Zvezdov (2013) propose that the development of management systems related to ecological factors and their application in factor cost control can make factor cost control activities more efficient [2] . Markus a (2016) links circular economy with enterprise cost control research and discusses how to use circular economy effectively in factor cost control [3]. Domestic research mainly focuses on environmental information and environmental quality . Chengang Ye et al (2015) studied from the institutional factors, market factors, public opinion factors and other factors constitute a dynamic system of environmental information disclosure [4]. Hua Xiao , Guoqing Zhang(2015) the state has also begun to gradually attach importance to environmental information and the establishment of open systems, to promote the assessment of Corporate Environmental Behavior Technical Guide [5] . Sixia Chen and Hong-you $\mathrm{Lu}$ (2014) pointed out that in view of the existence of negative externalities of production behavior, the flow of fiscal expenditure plays an important role in improving environmental quality [6] .

\section{Financial Status of Listed Coal Enterprises}

\subsection{Supply and Demand Analysis of Coal in China}

\subsubsection{Industry Fixed Asset Investment}

As can be seen from Figure 1, the overall growth rate of fixed asset investment slowed down from 2009 to 2019 , with many small speculative coal enterprises eliminated between 2009 and 2016 , and fixed investment turnover declined year by year, industry fixed assets investment reached the lowest end, but the annual new capacity is still maintained at a relatively high level, it can be seen that the domestic coal supply or a large number of

*Corresponding author:2590446318@qq.com 
existence

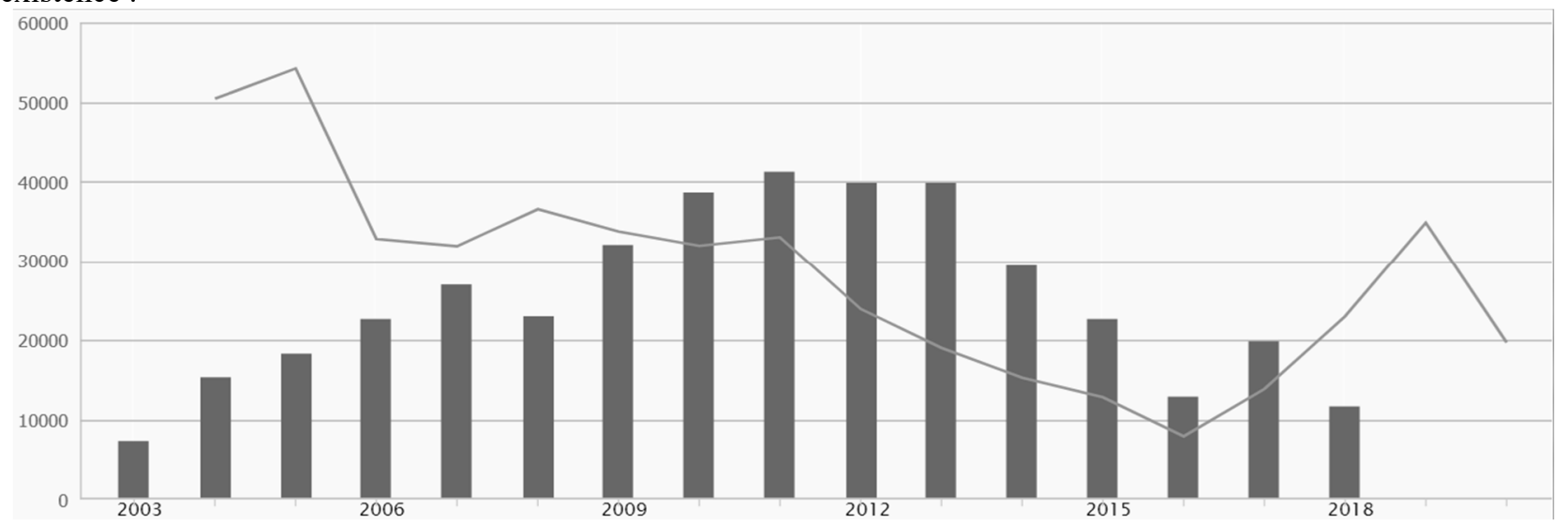

New production capacity for raw coal mining Coal industry fixed investment turnover : cumulative year-on-year (right)

Figure 1 Fixed Asset Investment Chart of Coal

\subsubsection{Output of the Four Major Downstream Industries}

Coal demand directly depends on the output growth rate of the downstream industries. As can be seen from Figure 2 , the output of the four major downstream industries from 2009 to 2016 showed a downward trend year by year. Coal demand is decreasing. Since 2016 , due to the implementation of supply-side reform, the excess capacity situation has improved, and in 2020 production in the four major downstream industries declined sharply due to the effects of 2020 , and coal demand has increased as the economy has gradually recovered .

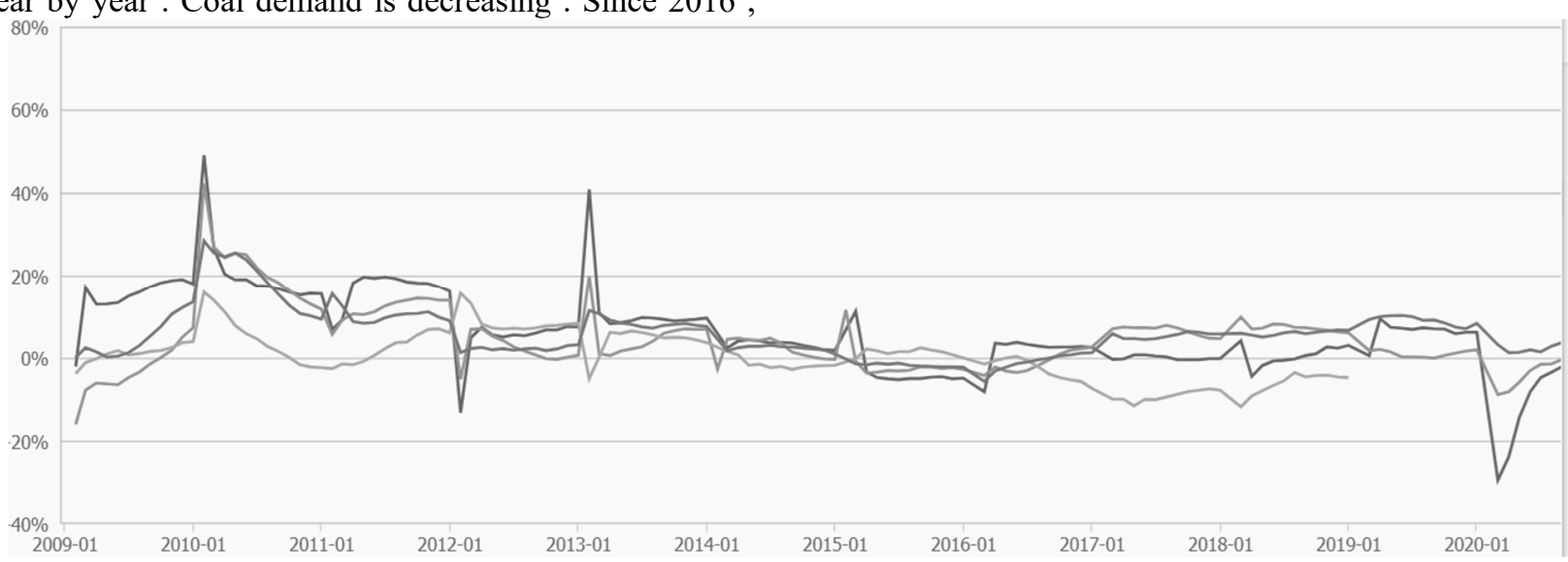

Fig . 2 Cumulative Year-on-Year Output of Coal Downstream Industry .

\subsection{Analysis on the Development Trend of Main Financial Indicators of Listed Coal Industry in China}

\subsubsection{Financial Development of the Industry}

In the financial development of the industry, the net profit of listed coal enterprises from 2010 to 2019 is used as the basis to judge the financial development of the industry, as shown in Table 1 :

Table 1 Industry Financial Development Statement

\begin{tabular}{|c|c|c|c|}
\hline & $\begin{array}{c}\text { Net Profit } \\
\text { (billion } \\
\text { yuan) }\end{array}$ & $\begin{array}{c}\text { Year-on-yea } \\
\text { r growth } \\
(\%)\end{array}$ & $\begin{array}{c}\text { M \& a } \\
\text { events } \\
\text { (events) }\end{array}$ \\
\hline 2010 & 790.02 & 34.29 & 33 \\
\hline 2011 & 933.85 & 14.71 & 15 \\
\hline
\end{tabular}

\begin{tabular}{|c|c|c|c|}
\hline 2012 & 840.19 & -12.35 & 23 \\
\hline 2013 & 609.58 & -28.01 & 7 \\
\hline 2014 & 390.11 & -39.77 & 16 \\
\hline 2015 & -45.39 & -111.21 & 28 \\
\hline 2016 & 322.43 & 889.42 & 23 \\
\hline 2017 & 842.62 & 156.52 & 34 \\
\hline 2018 & 944.85 & 8.56 & 16 \\
\hline 2019 & 909.38 & -1.24 & 16 \\
\hline
\end{tabular}

\subsubsection{Financial Situation of Coal Enterprises}

The factor protection tax law of the People's Republic of China has been implemented since January 1, 2018 . Taking the environmental protection tax of 20 coal enterprises in Table 2 as an example, this paper analyzes whether the collection of environmental protection tax has an impact on the profitability of enterprises, as shown in Table 2 : 
Table 220 Companies in 2018 Levy A Reakdown of Environmental Tax

\begin{tabular}{|c|c|c|}
\hline & $\begin{array}{c}\text { Environmental Tax } \\
\text { (Yuan) }\end{array}$ & $\begin{array}{c}\text { Environmental tax } \\
\text { rate (\%) }\end{array}$ \\
\hline Shaanxi coal industry & 7689430.38 & $0.18 \%$ \\
\hline Lu'an energy & 7210113.49 & $0.32 \%$ \\
\hline Open-pit coal & 1964942.99 & $1.09 \%$ \\
\hline Yang Quan Coal Industry & 2903866.45 & $0.48 \%$ \\
\hline Xishan Coal and Electricity Power & 3380711.77 & $0.32 \%$ \\
\hline Meijin energy & 4221104.68 & $5.56 \%$ \\
\hline Dry distillation, Shanxi & 4485525.51 & $9.70 \%$ \\
\hline Kailuan stock & 335692.98 & $0.08 \%$ \\
\hline Kinergy technologies & 7232717.19 & $2.86 \%$ \\
\hline Constant source coal power & 211860.72 & $0.06 \%$ \\
\hline Orchid Innovation & 1944285.28 & $0.45 \%$ \\
\hline Jizhong energy & 5041507.1 & $0.77 \%$ \\
\hline ST Antai & 278866.11 & $0.16 \%$ \\
\hline Datong coal & 592890.43 & $0.06 \%$ \\
\hline Jingyuan coal & 420811.7 & $0.37 \%$ \\
\hline Shaanxi Black Cat & 3515406.31 & $12.92 \%$ \\
\hline Cloud Coal Energy & 95810.2 & $0.35 \%$ \\
\hline Zhengzhou coal electricity & 3500257.34 & $3.71 \%$ \\
\hline Yongtai energy & 10582959.46 & $1.11 \%$ \\
\hline Pingzhuang energy & 901140.5 & $0.55 \%$ \\
\hline & & \\
\hline & & \\
\hline & & \\
\hline
\end{tabular}

\subsection{Financial Stress Analysis}

\subsubsection{Pressure for Sustainability}

As can be seen from the number of $\mathrm{M} \& \mathrm{~A} \mathrm{~S}$ in Table 1 , the number of $\mathrm{M} \& \mathrm{~A} \mathrm{~S}$ of listed coal enterprises decreased year by year before 2016 . This is because the policy has not yet been perfected, some small coal enterprises can still make profits and the financial pressure is less . Due to the improvement of policies and the promulgation of the national informatization plan for the 13th five-year plan, small enterprises have gradually been kicked out of the coal industry due to increased risks and high operating costs. As a result, the number of mergers and acquisitions by enterprises is increasing, coal Enterprises in the future direction of sustainable development is facing enormous pressure.

\subsubsection{Debt Servicing Pressure Analysis}

As you can see from Figure 3 , the balance sheet ratio peaked in 2015 . Since then, due to the impact of the supply-side reform policy, the coal industry has started to recover, the Coal Enterprises'asset-liability ratio has dropped year by year, and their debt-paying capacity has increased, however, due to the high asset-liability ratio caused by long-term losses in the past and the high production costs faced by enterprises under market and institutional factors, this high asset-liability ratio has not been fundamentally improved, the financial risks faced by companies remain high .

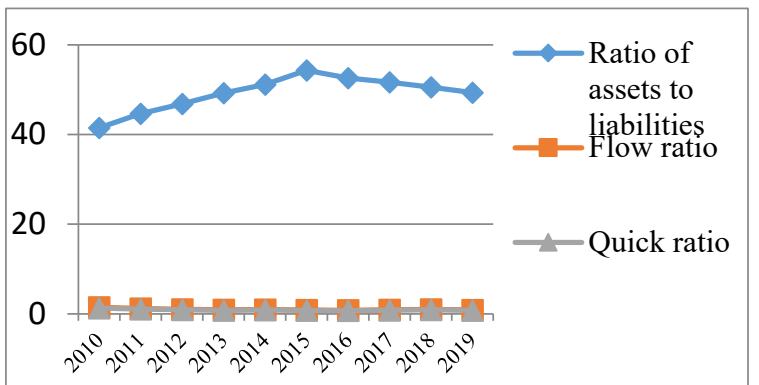

Fig .3 Analysis of Debt Repayment Pressure of Coal Enterprises

\subsubsection{Retention Pressure Analysis}

From Table 1 , we can see that before 2016 , the net profit of enterprises has been decreasing, and in 2015 , they reached the state of loss . After the supply-side reform was put forward in 2016 , the profitability of listed coal enterprises has been strengthened, but due to the increasing cost of coal mining, enterprise financial risk increases, and because the proportion of operating costs in revenue is larger, directly lead to enterprise profit less, even some enterprises are still in a loss state.

\subsubsection{Analysis of Operating Pressure}

Before 2016 related mining rights and the introduction of policies, so that the coal industry is not too depressed, enterprise credit sales increased, resulting in slow collection rate and inventory transfer rate was declining . After the supply-side reform policy was put forward, the inventory turnover rate and account receivable turnover rate were relatively improved, and the operating capacity of listed coal enterprises was significantly improved. 
However, due to the low utilization rate of assets in coal enterprises and the difficulty of financial management caused by informatization, the operating capacity of enterprises can not be effectively improved .

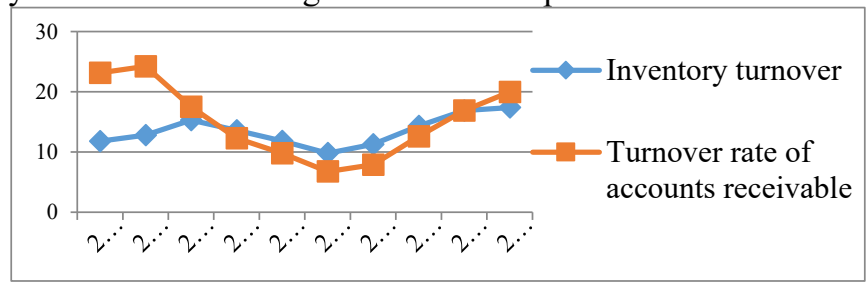

Fig . 4 Analysis of Operating Pressure in Coal Enterprises

As can be seen from the details of operating, debt servicing, profit and net profit presented by the 20 companies from 2015 to 2019 , each indicator increased between 2016 and 2017 , but showed a downward trend in 2018 , it can be seen from table 2 that although the proportion of environmental protection tax is small, it has some effect on the financial index of the whole coal listed company .

\subsubsection{Correlation among Indicators}

From Table 3 , we can see that almost all the indicators of profitability, debt service and operating capacity have certain relevance, which validates the correctness of our index selection, there is a certain negative correlation between the profitability and the debt-paying ability of the enterprise, and the two influence each other. The greater the enterprise' $s$ asset-liability ratio, the greater the debt-paying pressure it faces, and the lower the sales gross profit rate of the enterprise, etc ., that is, the more pressure there is on companies to make money . There is also a positive correlation between debt repayment and operating capacity, but the significance is not obvious.

Table 3 Correlation Analysis of Each Index

\begin{tabular}{|c|c|c|c|c|c|c|c|c|}
\hline & $\begin{array}{l}\text { Gross } \\
\text { margin } \\
\text { on sales }\end{array}$ & $\begin{array}{l}\text { NET } \\
\text { interest rate } \\
\text { on sales }\end{array}$ & $\begin{array}{l}\text { Ratio of } \\
\text { assets to } \\
\text { liabilities }\end{array}$ & $\begin{array}{l}\text { Ratio of } \\
\text { total assets } \\
\text { to liabilities }\end{array}$ & $\begin{array}{l}\text { Turnover } \\
\text { rate of } \\
\text { accounts } \\
\text { receivable }\end{array}$ & $\begin{array}{l}\text { Inventory } \\
\text { turnover }\end{array}$ & $\begin{array}{l}\text { Flow } \\
\text { ratio }\end{array}$ & $\begin{array}{l}\text { Quick } \\
\text { ratio }\end{array}$ \\
\hline $\begin{array}{l}\text { Gross margin on } \\
\text { sales }\end{array}$ & 1 & $.658^{* *}$ & $-.315^{* *}$ & $-.168^{*}$ & .052 & -.033 & -.036 & -.027 \\
\hline $\begin{array}{l}\text { NET interest rate } \\
\text { on sales }\end{array}$ & & 1 & $-.487^{* *}$ & .129 & $.178^{*}$ & .059 & .066 & 062 \\
\hline $\begin{array}{l}\text { Ratio of assets to } \\
\text { liabilities }\end{array}$ & & & 1 & -.094 & .007 & .075 & $-.397^{* *}$ & $-.394^{* *}$ \\
\hline $\begin{array}{l}\text { Ratio of total assets } \\
\text { to liabilities }\end{array}$ & & & & 1 & $.383^{* *}$ & $.171^{*}$ & $511^{* *}$ & $481^{* *}$ \\
\hline $\begin{array}{l}\text { Turnover rate of } \\
\text { accounts receivable }\end{array}$ & & & & & 1 & .119 & -.143 & $-.173^{*}$ \\
\hline Inventory turnover & & & & & & 1 & .034 & 068 \\
\hline Flow ratio & & & & & & & 1 & $997^{* *}$ \\
\hline Quick ratio & & & & & & & & 1 \\
\hline
\end{tabular}

\section{Conclusions}

Through the analysis of the financial pressure of listed coal enterprises, we can see that the pressure of sustainable development, the ability of paying debts, the pressure of keeping profits and the pressure of operation are all increasing, which leads to the difficulty of enterprise transformation. Therefore, it is necessary to strengthen cost control and asset management, improve advance forecasting and control coordination, conduct regular inventory, optimize capital structure, strengthen internal control and external relationship management, and speed up enterprise information construction, we will strengthen the identification and monitoring of financial risks, realize the transformation of financial management resources sharing, and improve the ability of enterprises to cope with financial pressures .

\section{References}

1. Son H, Kim C, Kim H, et al. Trend analysis of research and development on automation and robotics technology in the construction industry[J]. Ksce Journal of Civil Engineering , 2010, 14(2) : 131-139.

2. Stefan Schaltegger, D Zvezdov Reducing Operational and Prod-Costs through Environmental Accounting $[\mathrm{J}]$. Environmental Quality Management Spring, 2013, (11). 
3. Markus A. The research of circular economy and the enterprise environment cost control [J]. Journal of Cleaner Prosuction ,2016,1(3) : 215 - 217.

4. Chengang $\mathrm{Ye}, \mathrm{Zi}$ Wang, Jianfeng $\mathrm{Wu}$, et al. . External governance, factor information disclosure and cost of equity financing $[\mathrm{J}]$. Nankai management review, 2015, 18(5) : 85-96.

5. Hua Xiao , Guoqing Zhang . Public pressure and disclosure of corporate factors : an empirical study based on the Songhua River event $[\mathrm{J}]$. Accounting Research, 2008(5) : 15-22 .

6. Sixia Chen, Hongyou Lu . Public Expenditure Structure and factor quality: an empirical analysis of China [J] . Economic Review , 2014(1) : 70-80 . 